\title{
固体電解質型燃料電池用空気側集電体の開発
}

\author{
村田和俊・泉 政明・下津正輝 \\ 三井造船 (株)機械制御技術開発センター, 706-0014 岡山県玉野市玉原 3-16-1
}

\section{Development of the Air Side Current Collector for Solid Oxide Fuel Cells}

Kazutoshi MURATA, Masaaki IZUMI and Masateru SHIMOTSU

Tamano Technology Center, Mitsui Engineering and Shipbuilding Co., Ltd., 3-16-1, Tamahara, Tamano-shi, Okayama 706-0014

\begin{abstract}
An air side current collector (ASCC) for a solid oxide fuel cells (SOFC) was fabricated and evaluated. Thirty mass \% YSZ-LSM, was selected as a candidate material for ASCC. Its electrical conductivity at $1000^{\circ} \mathrm{C}$ and its average thermal expansion coefficient between room temperature and $1000^{\circ} \mathrm{C}$ were $65 \mathrm{~S} \cdot \mathrm{cm}^{-1}$ and $10.9 \times 10^{-6} \mathrm{~K}^{-1}$, respectively. The gas channel width of ASCC is very important factor, because the current collecting resistance depends on it strongly. A $1 \mathrm{~cm}^{2}$ cell was operated with different current collecting length, which corresponded to the width of the gas channel. We made it clear that the current collecting resistance was very small when the channel width was $\leqq 3 \mathrm{~mm}$. The SOFC short-stack was built with a 140 $\mathrm{cm}^{2}$ cell and two ceramic gas separators. The separator was composed of $\mathrm{MgO}-\mathrm{MgAl}_{2} \mathrm{O}_{4}$ separate plates, $\mathrm{La}(\mathrm{Sr}) \mathrm{CrO}_{3}$ current passages and current collectors. The electric power generation test was carried out at $1000^{\circ} \mathrm{C}$ for $700 \mathrm{~h}$. The cell attained the output power $36 \mathrm{~W}$ at the current $48 \mathrm{~A}$. The voltage loss at the gas separator with a current $45 \mathrm{~A}$ was $68 \mathrm{mV}$, accordingly the electric resistance of the separator was $1.5 \mathrm{~m} \Omega$. The electric resistance did not change after a thermal cycle conducted between $1000^{\circ} \mathrm{C}$ and room temperature.

[Received June 9, 1999; Accepted September 14, 1999]
\end{abstract}

Key-words : $\mathrm{SOFC}$, Current collector, Gas separator, $\mathrm{La}(\mathrm{Sr}) \mathrm{MnO}_{3}$, Electrical conductivity

\section{1. 緒 言}

固体電解質型燃料電池 (SOFC) は, 高いエネルギー変換効 率を有する新しい発電システムとして, その実用化が期待され ている1). 著者らは高出力密度化と低コスト化が期待できる平 板型 SOFC の開発を進めている. 平板型 SOFC は発電素子で あるセルとそのセルにガスを供給するガスセパレーターから構 成される. 著者らの開発しているガスセパレーターは, 電気絶 縁性の $\mathrm{MgO}-\mathrm{MgAl}_{2} \mathrm{O}_{4}$ （以下 $\mathrm{MA}$ と略記）製の隔離板に, 電 気伝導性の $\mathrm{La}(\mathrm{Sr}) \mathrm{CrO}_{3}$ (以下 $\mathrm{LSC}$ と略記）製の電子通路を 接合したものである ${ }^{2), 3}$. その構造上, セパレーターの面内方 向には電気伝導性がなく，これを確保するために集電体を組み 込み，ガスセパレーターを完成させている，この集電体は，

(1) セルと電子通路との電気接続, (2) セル電極面へのガス供 給の役割を担う. 集電体材料に求められる特性としては，(1) 熱膨張係数の他部材との整合性, (2) 高い電気伝導性, (3) 化 学的安定性などがあげられる. また, 集電体の溝幅, 厚みな ど, その形状を適正化することにより, セル性能を最大限に引 き出すことができる.

著者らはこれまで, 空気側集電体 (air side current collector, 以下 ASCC と略記), 材料には $\left(\mathrm{La}_{0.85} \mathrm{Sr}_{0.15}\right)_{0.85} \mathrm{MnO}_{3}$ (以 下 LSM と略記) を, 燃料側集電体 (fuel side current collector, 以下 FSCC と略記）材料には， $40 \mathrm{vol} \% \mathrm{Ni}-\mathrm{YSZ}$ を採用 してきた. SOFCはその一般的な作動温度である $1000^{\circ} \mathrm{C}$ と室 温との間の熱サイクルにさらされる.このとき, 集電体と他の 部材との熱膨張係数の違いにより, 電気接続点の接触が悪くな ることがある.この現象は電気伝導度の低い空気側で特に問題 となる.したがって ASCC 材料の熱膨張係数をセル, MA 板 のそれに近づける必要がある.

そこで本研究では, ASCC 材料としてイットリア安定化ジ ルコニア（以下 YSZ と略記）を添加したLSM を取り上げ, その電気伝導性及び熱膨張係数について調査した. また，小さ なセルの発電実験により, 集電体形状の重要な因子である溝幅
について検討を行った. 最後に, 本研究により作製評価した集 電体をスタックに組み达み, その発電試験を行い, セルの特性 及びガスセパレーターの電気抵抗について調べた。

\section{1 試料作製}

\section{2. 実 験}

$x$ mass $\%$ YSZ-LSM $(x=0,10,20,30,40,50)$ の作製は以下 のように行った. LSM 合成の出発原料には各酢酸塩を用い,

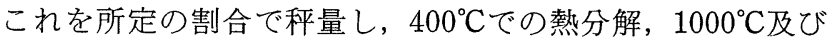
$1200^{\circ} \mathrm{C}$ での 2 回の固相反応により $\left(\mathrm{La}_{0.85} \mathrm{Sr}_{0.15}\right)_{0.85} \mathrm{MnO}_{3}$ 粉末 を得た4). 一方, YSZ粉末には, $8 \mathrm{~mol} \%$ イットリア安定化シ ルコニア粉末（東ソ一製，TZ-8Y）を用いた。この LSM 粉 末と YSZ 粉末とを所定の割合ではかり取り, 混合, プレス成 形, 仮焼, 粉砕, プレス成形, $1500^{\circ} \mathrm{C} \times 5 \mathrm{~h}$ の焼成を行った。こ の焼成体は相対密度 $90 \%$ 以上であった。これを $2 \times 2 \times 20 \mathrm{~mm}^{3}$ 及び $3 \times 3 \times 17 \mathrm{~mm}^{3}$ に機械加工して，それぞれを電気伝導 度測定用，及び熱膨張係数測定用の試料とした。電気伝導度 は空気中に抢いて直流 4 端子法により測定した。また，熱膨 張係数は理学電機製 TMA8140を用いて, 空気中で室温から $1000^{\circ} \mathrm{C}$ な゙の温度域で測定した. YSZ と LSM との反応性は, $1500^{\circ} \mathrm{C}$ 焼成体を試料とし，これを $\mathrm{X}$ 線回折分析することによ り調べた。

集電体作製には LSM 粉末と YSZ 粉末とを所定の割合では かり取り，ボールミルを用いて $24 \mathrm{~h}$ 混合することにより，集 電体の原料粉末を得た. この粉末とバインダー（メチルセル ロース), 可塑剤（グリセリン）, 滑剤（ステアリン酸エマル ショョン), 水を混合し, 押出法により, 溝付き板状に成形した. これを $1400^{\circ} \mathrm{C} \times 5 \mathrm{~h}$, 空気中で焼成し, 機械加工を加えて, 集 電体を完成させた. 作製した集電体の形状を図 1 に示す.

\section{2 発電試験}

集電体の溝幅を検討することを目的とし, 図 2 に示すセルの 発電試験を行った。 セルは厚さ $400 \mu \mathrm{m}$ の YSZ 電解質, 厚さ 


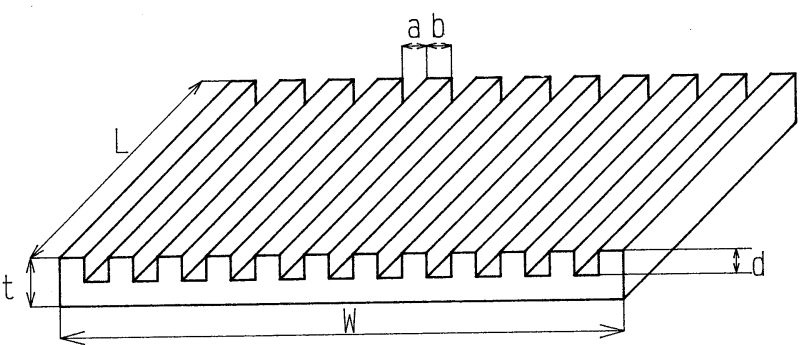

W : Width of the Current Collector, $150 \mathrm{~mm}$

$\mathrm{L}$ : Length of the Current Collector, $94 \mathrm{~mm}$

$\mathrm{t}$ : Thickness of the Current Collector, $1.5 \mathrm{~mm}$

$\mathrm{a}$ : Width of the gas channel, $1.2 \mathrm{~mm}$

$\mathrm{b}$ : Width of the rib, $1.2 \mathrm{~mm}$

$\mathrm{d}$ : Depth of the gas channel, $0.75 \mathrm{~mm}$

Fig. 1. Schematic view of the current collector.

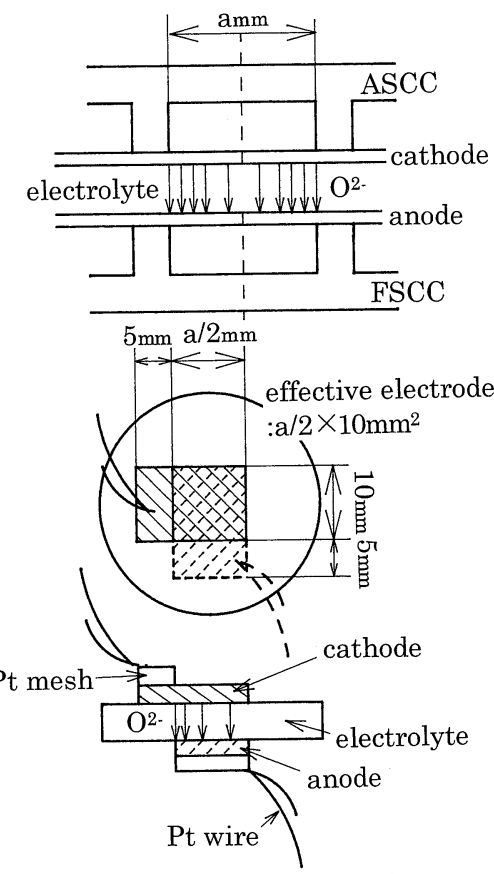

$\mathrm{a}:$ Width of the gas channel

a/2 : Current collecting length

CASE-1 : Pt mesh was applied on the $\mathrm{a} / 2 \times 10 \mathrm{~mm}^{2}$ area.

CSEE- $2: \mathrm{a} / 2=5.5 \mathrm{~mm}$

CASE $-3: a / 2=10 \mathrm{~mm}$

Fig. 2. Schematic diagram of the small cell which was tested to evaluate the effect of the current collecting length for the cell performance.

$150 \mu \mathrm{m}$ の空気電極, 及び燃料電極より構成される5). 発電電 極は $(a / 2) \times 10 \mathrm{~mm}^{2}$ である. その横に集電電極として, 空気 側には $5 \times 10 \mathrm{~mm}^{2}$ の, 燃料側には $(a / 2) \times 5 \mathrm{~mm}^{2}$ の領域を設 けた，集電電極上には Pt 網を焼き付け，Pt 線により電流を取 り出した，発電電極にも $\mathrm{Pt}$ 網を用いて，全面集電を行った場 合をCASE-1, 集電距離 $(a / 2)$ が $5.5 \mathrm{~mm}, 10 \mathrm{~mm}$ の場合をそ れぞれ CASE-2, 及び CASE-3 とした。発電は温度 $1000^{\circ} \mathrm{C}$ おいて，然料に水素を，酸化剂に空気を用いて行った。 セルの 分極成分はカレントインタラプション法6)によ IR 成分と分 離して測定した.

作製した集電体を総合的に評価することを目的とし，ショー トスタックを作製し，その発電試験を行った．このスタックは 1 枚のセルと 2 枚のガスセパレーターより構成される. セルの

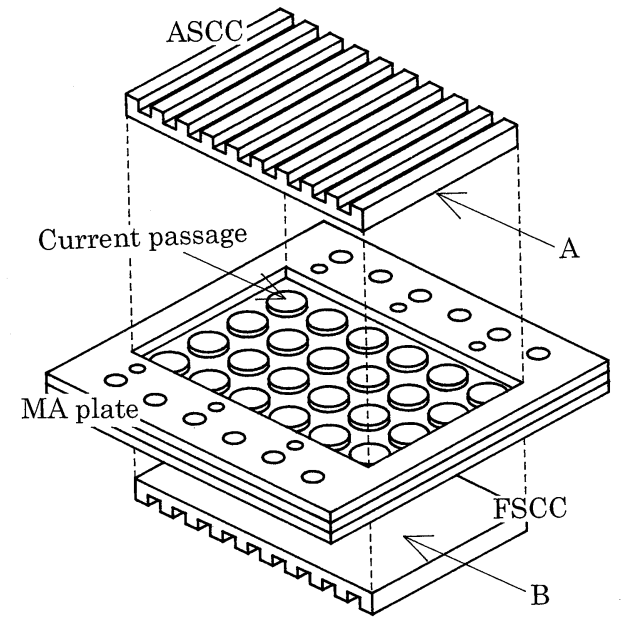

A,B : Positions for the electric potential measurement.

Fig. 3. Schematic view of the ceramic gas separator.

Table 1. Components for the Gas Separator

\begin{tabular}{cccrc}
\hline Component & Material & Size $/ \mathrm{mm}^{3}$ & $\sigma$ & $\alpha$ \\
\hline MA-plate & MgO-MgAl2O 4 & $180 \times 180 \times 5.6$ & - & 10.8 \\
CP & La(Sr)CrO3 & $\phi 18 \times 1.0$ & 32 (air) & 10.1 \\
ASCC & YSZ-LSM & $150 \times 94 \times 1.5$ & 65 & 10.9 \\
FSCC & Ni-YSZ & $150 \times 94 \times 1.5$ & 1200 & 12.0 \\
\hline
\end{tabular}

CP: Current Passage.

ASCC : Air side current collector.

FSCC : Fuel side current collector.

$\sigma:$ Electrical conductivity at $1000^{\circ} \mathrm{C} .\left(\mathrm{Scm}^{-1}\right)$

$\alpha$ : Average thermal expansion coefficient between room temperature and $1000^{\circ} \mathrm{C} .\left(10^{6} \mathrm{~K}^{-1}\right)$

電解質は $8 \mathrm{~mol} \% \mathrm{YSZ}$, その有効電極面積は $140 \mathrm{~cm}^{2}$ である. 図 3 にはガスセパレーターの模式図を示す。ガスセパレーター は表 1 に示す部材より構成される。これらのセルとガスセパ レーターとを積層し, スタックを得た。発電試験は温度

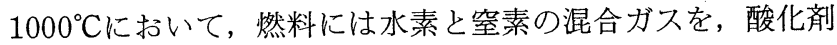
には空気を用いて行った. 図 3 に示すように, 集電体の背面 （A 点及び $\mathrm{B}$ 点）に電位測定用の $\mathrm{Pt}$ 線を挿入し，これを用い てセル電圧，ガスセパレーターでの電圧損失を求めた。

\section{1 集電体材料}

\section{3. 結果及び考察}

図 4 には $x$ mass\%YSZ-LSM の空気中 $1000^{\circ} \mathrm{C}$ における電気 伝導度を示す．横軸には YSZ の重量割合を, 縱軸には電気伝 導度を示す. $x=0$ の純 LSM $91000^{\circ} \mathrm{C} に$ 抢ける伝導度は 160 $\mathrm{S} \cdot \mathrm{cm}^{-1}$ であった. YSZ 混合割合を増やすに従い伝導度は低下 し， $x=30$ のそれは $65 \mathrm{~S} \cdot \mathrm{cm}^{-1}$ であった. $x=40 て ゙ は 30 \mathrm{~S} \cdot \mathrm{cm}^{-1}$ となり, $x=30$ の約半分の值となった。 また, 図 5 には電気伝 導度の温度依存性を示す。いずれの試料も, その伝導度は Arrhenius プロットで直線上にあり，その活性化エネルギーは11 $\mathrm{kJ} \cdot \mathrm{mol}^{-1}$ であった. いずれの試料でも LSM の連続相が形成 され，その相が電流パスとなっていることが示唆される. 図 6 には30 mass\%YSZ-LSMのX線回折分析の結果を示す. LSM と YSZ のピークのみが観察され， $\mathrm{La}_{2} \mathrm{Zr}_{2} \mathrm{O}_{7}$ などの反応 生成物7),8) は確認されなかった。

図 7 には $x=0,30$, 及び純 YSZ の熱膨張率の測定結果を示 


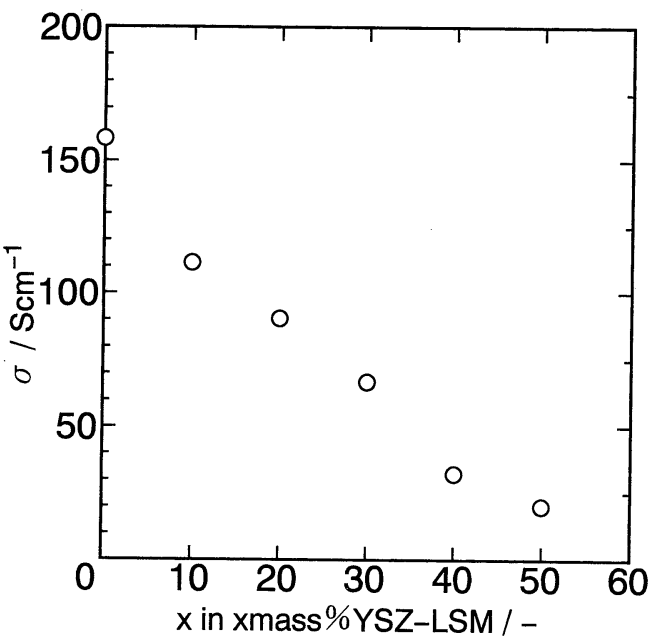

Fig. 4. Electrical conductivity of $x$ mass $\% \mathrm{YSZ}-\mathrm{LSM}$ at $1000^{\circ} \mathrm{C}$ in air.

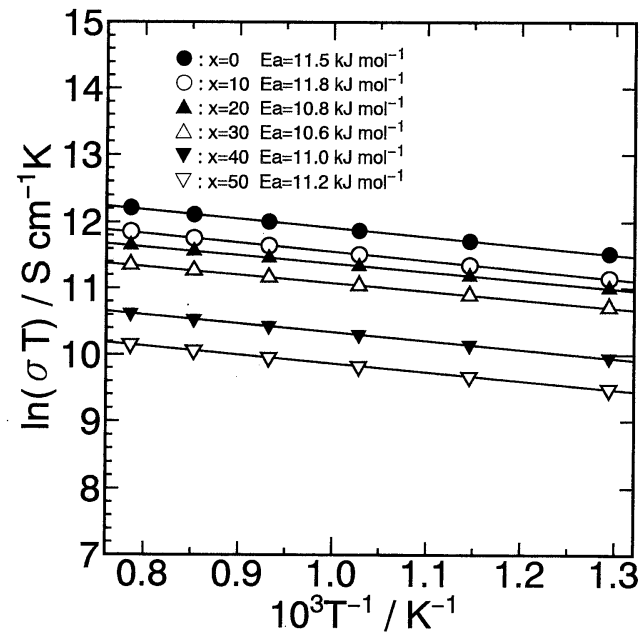

Fig. 5. Electrical conductivity of $x$ mass\%YSZ-LSM in air as a function of temperature.

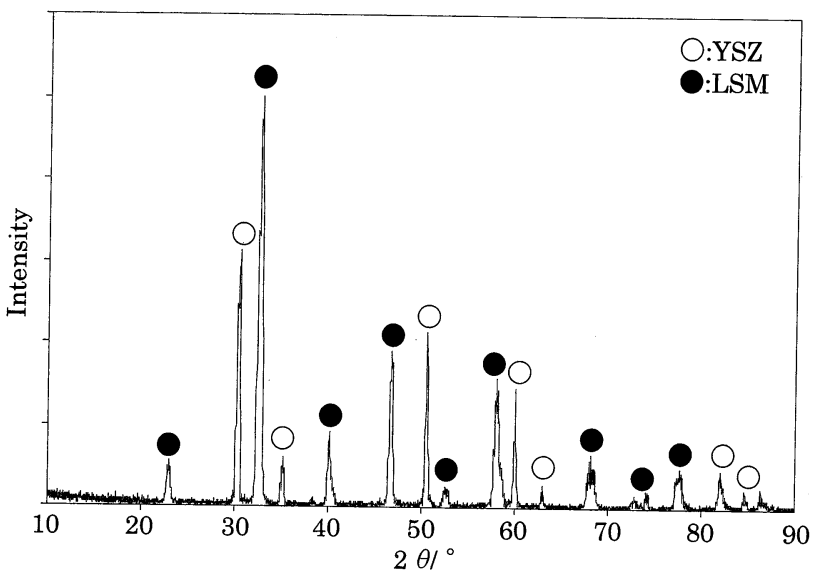

Fig. 6. X-ray diffraction pattern of 30 mass\%YSZ-LSM which was sintered at $1500^{\circ} \mathrm{C}$ for $5 \mathrm{~h}$.

す. 室温と $1000^{\circ} \mathrm{C}$ 間の平均線膨張係数は $x=0$ では $11.3 \times 10^{-6}$ $\mathrm{K}^{-1}, x=30$ では $10.9 \times 10^{-6} \mathrm{~K}^{-1}$, 純 $\mathrm{YSZ}$ のそれは $10.6 \times 10^{-6}$ $\mathrm{K}^{-1}$ であった. YSZ 30 mass\%添加することにより集電体材

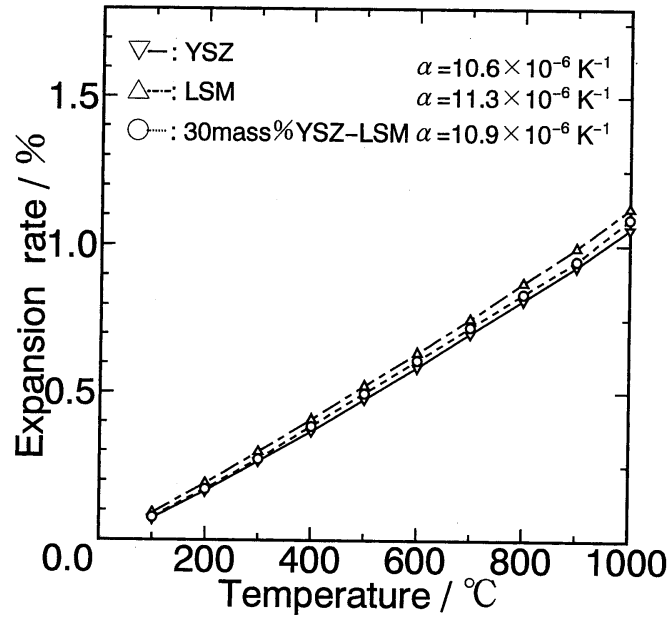

Fig. 7. Thermal expansion rates of 30 mass\%YSZ-LSM, LSM and YSZ.

料の熱膨張係数を YSZのそれに近づけることができた。 上述 した電気伝導度の測定結果と併せ，30 mass\%YSZ-LSM を適 正組成とした。

\section{2 集電体溝幅の検討}

小セルの発電結果を図 8 に示す，発電電極の全面で集電する CASE-1 では, 最大出力 $0.50 \mathrm{~W} \cdot \mathrm{cm}^{-2}$ が得られた。 集電距離 が5.5 mm, 及び $10 \mathrm{~mm}$ である CASE-2, 及び CASE-3 のと き，その最大出力はそれぞれ $0.35 \mathrm{~W} \cdot \mathrm{cm}^{-2}, 0.22 \mathrm{~W} \cdot \mathrm{cm}^{-2}$ で あった．セル出力は集電距離に大きく影響された．表 2 には

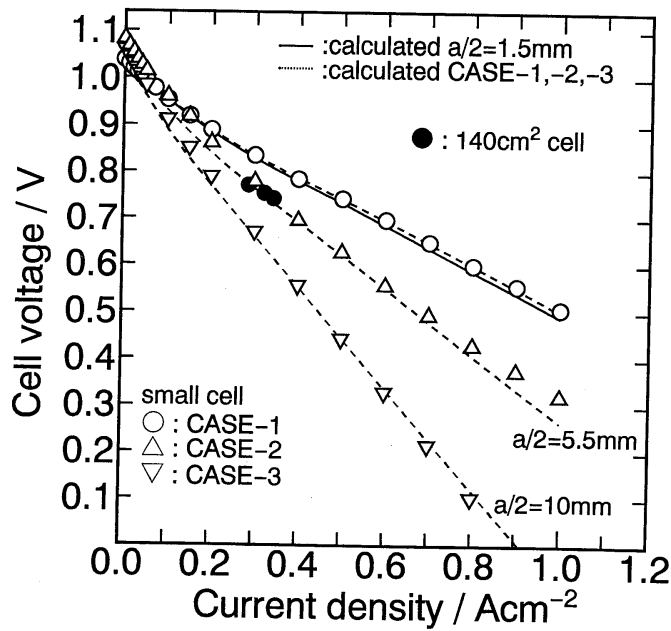

Fig. 3. Effect of the current collecting length for the performance of the small cell at $1000^{\circ} \mathrm{C}$. The humidified hydrogen and the air were fed to the cell as a fuel and an oxidant, respectively.

Table 2. Effect of the Current Collecting Length for the Cell Performance

\begin{tabular}{lcccc}
\hline & E/V & EiR/V & $\eta$ air/V & MPD/Wcm ${ }^{2}$ \\
\hline CASE-1 & 0.600 & 0.198 & 0.040 & 0.50 \\
CASE-2 & 0.429 & 0.333 & 0.155 & 0.35 \\
CASE-3 & 0.139 & 0.525 & 0.318 & 0.22 \\
\hline
\end{tabular}

$\mathrm{E}$ : Cell voltage at the current density $0.8 \mathrm{Acm}^{-2}$.

EIR : IR loss at the current density $0.8 \mathrm{Acm}^{-2}$.

$\eta$ air: Cathodic overpotential at the current density $0.8 \mathrm{Acm}^{2}$.

MPD: maximum power density of the cell. 


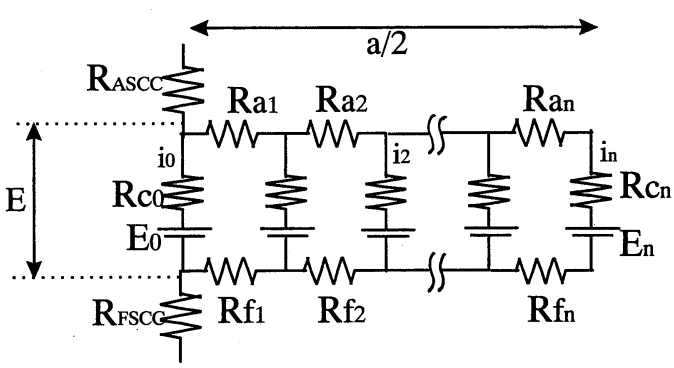

$\mathrm{R}_{\mathrm{ASCC}}, \mathrm{R}_{\mathrm{FSCC}}$ IR resistance of the rib of the current collector.

$\mathrm{Ra}$ : IR resistance of the cathode in the lateral direction.

$\mathrm{Rf}$ : IR resistance of the anode in the lateral direction.

Rc: Inner resistance of the cell calculated from the performance $O$ in Fig.8. Polarization resistance at the electrode is involved in Rc. E: Cell voltage.

$\mathrm{a} / 2$ : Current collecting length.

Fig. 9. Equivalent circuit model for the current collecting of the small cell.

$0.8 \mathrm{~A} \cdot \mathrm{cm}^{-2}$ における IR 損失とカソード分極值を示す. 集電距 離を大きくすると, IR 損失, 分極值のいずれも大きくなった. これはカソード膜の電気伝導度が十分でないために，集電距離 の長い電極部は有効に作動していないことを示唆する.すなわ ち実効電極面積は見かけ上の有効電極 $a / 2 \times 10 \mathrm{~mm}^{2}$ より小さ く，その結果として IR 損失と分極值とのいずれもが大きく なったと考えられる.

そこで図 9 に示すモデルを用いて各集電距離でのセル性能を 計算した． $R_{\mathrm{ASCC}}$ ，及び $R_{\mathrm{FSCC}}$ は集電体リブ部の IR 抵抗であ り,このリブによりセル電極と集電体とが電気的に接続され る. $R_{\mathrm{a}}$ は空気電極の, $R_{\mathrm{f}}$ は燃料電極の水平方向の IR 抵抗で ある，集電体リブから離れたところに位置するセル電極部で は，電極内を水平方向に電流が流れることにより，有効電極と して作用する. 空気電極, 及び燃料電極の比抵抗值はそれぞれ $0.04 \Omega \cdot \mathrm{cm}, 0.003 \Omega \cdot \mathrm{cm}$ ，膜厚は双方とも $150 \mu \mathrm{m}$ とした. $R_{\mathrm{c}}$ はセルの全内部抵抗であり, 電極での分極成分もこの中に含ま れる.この $R_{\mathrm{c}}$ を図 8 の○印で示した CASE-1 の実測データよ り，電流密度の関数として表した. 図 9 のモデルを用いて, CASE-2 及び CASE-3 の場合について，セル性能の計算を 行った. $R_{\mathrm{a}}$ （カソード内水平方向の IR 抵抗）が大きいため に, $i_{0}>i_{1}>\cdots>i_{n}$ となった． また，各要素セルを流狆る電流 の総和，すなわち全電流 $i$ に対するセル電圧 $E$ の計算結果を，

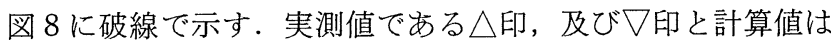
比較的良い一致を示す.この結果を基に集電距離 $a / 2=1.5$ $\mathrm{mm}$ （電体溝幅 $a=3 \mathrm{~mm}$ に相当）について，セル性能予測を 行った。その結果を図 8 に実線で示す。全面集電である CASE-1 と, ほぼ同等のセル性能が得られている. 集電抵抗 を小さくすることに着目した場合, 集電体の溝幅は $3 \mathrm{~mm}$ 以 下が適当であると結論した

\section{3 スタック発電試験}

本研究で作製評価した集電体を，総合的に評価することを目 的とし，ショートスタックを作製し，その発電試験を実施し た。スタック発電性能を図10に示す。スタック電流 $48 \mathrm{~A}$ （セ ル電流密度 $\left.0.34 \mathrm{~A} \cdot \mathrm{cm}^{-2}\right)$ において, セル電圧 $0.75 \mathrm{~V}$, セル出 力 $36 \mathrm{~W}$ を記録した．セル 1 枚とガスセパレーター 1 枚での出

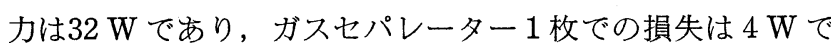
あった．本セルの性能を電流密度で整理した結果を図 8 の

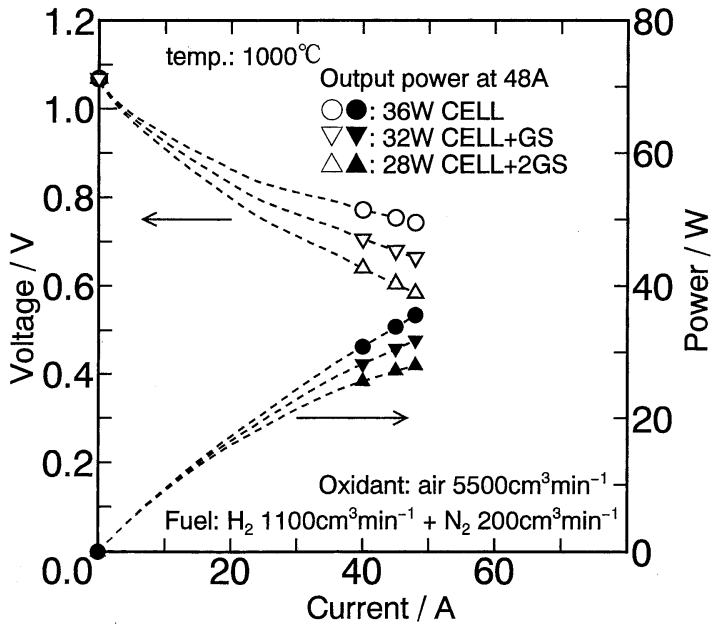

Fig. 10. $I-V$ and $I-P$ characteristics of the short stack at $1000^{\circ} \mathrm{C}$. The electrode area of the cell was $140 \mathrm{~cm}^{2}$.

印に示す. 電流密度 $0.3 \mathrm{~A} \cdot \mathrm{cm}^{-2}$ におけるセル電圧は $0.76 \mathrm{~V}$ で あった. 全面集電である CASE-1 でのセル電圧 $0.84 \mathrm{~V}$ と比較 すると，そのセル電压は約 $90 \%$ であった．セル発電面積が 140 倍であることを考慮すると，この集電抵抗は非常に小さい. た, この結果は, セル電極への燃料ガス, 及び酸化剤ガスの供 給が，スムーズに行われていることを示す．図11にはガスセパ レーターの電気抵抗測定結果を示す。この抵抗值は，ガスセパ レーターでのIR 損失を, スタック電流值で除したものであ る. 発電開始後 $150 \mathrm{~h}$ まで抵抗值は減少していき，それ以降ほ ぼ一定の值を示した． 2 枚のガスセパレーターの抵抗值は，そ れぞれ $1.5 \mathrm{~m} \Omega, 1.7 \mathrm{~m} \Omega$ であった．例えば，ガスセパレーター に $45 \mathrm{~A}$ の通電を行うと, $68 \mathrm{mV}, 77 \mathrm{mV}$ の電圧損失が起こる. 発電開始後 $460 \mathrm{~h}$ 時点で, 室温までの熱サイクル試験を実施し た. 熱サイクル直後の抵抗值は $6 \mathrm{~m} \Omega$ 程度となったが，時間経 過とともに，また，通電量を大きくするに伴ない，抵抗值は 徐々に小さくなった. 約 $600 \mathrm{~h}$ 経過時には, 熱サイクル前の值 に回復した。熱サイクル直後の大きな抵抗値は，ショートス タック端面と金属製ガスマニホールドとの電気接触に起因する と考えている，ただし，詳細については別途検討する必要があ る.

このショートスタック発電試験により，今回作製評価した ASCC を組み込んだガスセパレーターの電気抵抗は, $1.5 \mathrm{~m} \Omega$

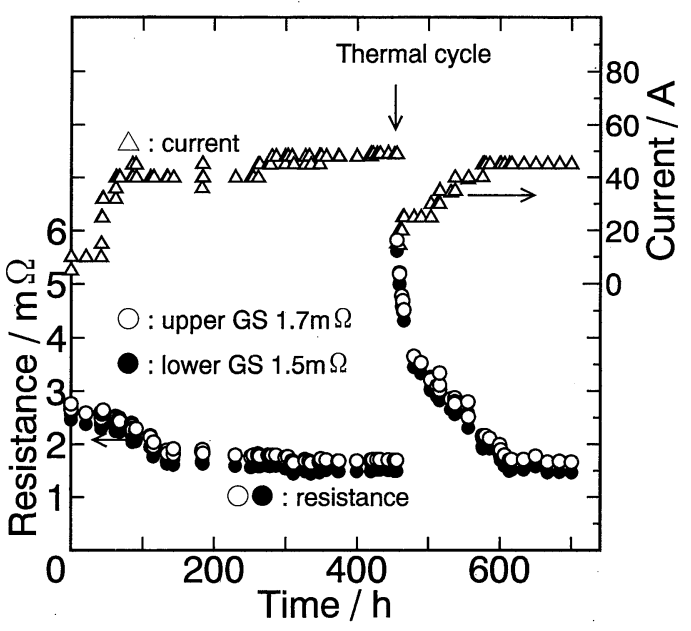

Fig. 11. Resistance of the gas separators during $700 \mathrm{~h}$ operation. 
程度と小さく，その抵抗値は熱サイクル試験後も変化しないこ とを確認した。

\section{4. 結 言}

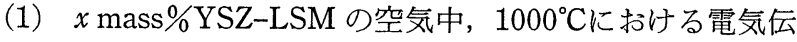
導度を測定した. $x=30$ の伝導度は $65 \mathrm{~S} \cdot \mathrm{cm}^{-1}$ であり，その活 性化エネルギーは純 LSM と同等であったまた，その線膨張 係数は $10.9 \times 10^{-6} \mathrm{~K}^{-1}$ であり, YSZの值に近いものであっ た.

(2) 集電体溝幅の検討を小セルでの発電試験により行っ た.その結果，溝幅を $3 \mathrm{~mm}$ 以下にすることにより，全面集 電と同等の性能が得られることを明らかにした。

（3）作製した集電体をガスセパレーターに組み込み，ス タックの発電試験を実施し, 集電体の総合的な評価を行った. 有効電極面積 $140 \mathrm{~cm}^{2}$ のセルで出力 $36 \mathrm{~W}$ が得られ, 高い集電 性能を検証した．また，ガスセパレーターの電気抵抗は 1.5 $\mathrm{m} \Omega$ と小さく, 耐熱サイクル性にも優れていることを確認し た

\section{文献}

1) N. Q. Minh, J. Am. Ceram. Soc., 76, 563-68 (1993).

2) M. Izumi and M. Shimotsu, J. Ceram. Soc. Japan, 107, 349-52 (1999) [in Japanese].

3) K. Murata, M. Izumi and M. Shimotsu, Mitsui Zosen Technical Review, 154, 6-12 (1995) [in japanese].

4) K. Katayama, T. Ishihara, H. Ohta, S. Takeuchi, Y. Esaki and E. Inukai, J. Ceram. Soc. Japan (Seramikkusu Ronbunshi), 97, 1327-33 (1989)

5) K. Murata and M. Shimotsu, Proc. of the 5th Symp. on Solid Oxide Fuel Cells in Japan (1996) pp. 35-38 [in Japanese].

6) A. Fujishima, M. Aizawa and T. Inoue, "Denki Kagaku Sokuteiho," Gihodo-Shuppan (1987) pp. 271-87 [in Japanese].

藤嶋 昭, 相澤益男, 井上祥隆, “電気化学測定法, ”技報堂 出版 (1987) pp. 271-87.

7) O. Yamamoto, Y. Takeda, R. Kanno and M. Noda, Solid State Ionics, 22, 241-46 (1987).

8) H. Yokokawa, N. Sakai, T. Kawada and M. Dokiya, J. Electrochem. Soc., 138, 2719-27 (1991). 